\title{
RECONCILIATION OF TEMPERATURE-DEPTH PROFILES IN POLAR ICE SHEETS WITH PAST SURFACE TEMPERATURES DEDUCED FROM OXYGEN-ISOTOPE PROFILES
}

\author{
By G. DE Q. RoBin \\ (Scott Polar Research Institute, Cambridge CB2 IER, England)
}

\begin{abstract}
ABSTRACr. Investigations of isotopic and temperature profiles in polar ice sheets were mostly carried out independently of one another until 1973 when a workshop dealing with both topics was held in Cambridge. Studies of temperature profiles show the approximate validity of theoretically derived temperature distributions for steady-state models of ice sheets, while other analyses help to determine departures from the steady state. The review gives some idea of the degree of accuracy of various solutions arising from studies of the heat flow and temperature distribution of ice sheets. Much of this knowledge is directly applicable to interpretation of isotopic profiles if a direct correspondence between mean isotopic $\delta$ values and mean annual temperatures can be established. The paper therefore reviews various methods of comparing $\delta$ values and temperatures, and shows that for central regions of polar ice sheets a reasonably consistent relationship
\end{abstract} between these factors does exist.

RÉsumÉ. Compatibilité des profils températures-profondeurs dans les calottes polaires avec les températures passées de la surface telles qu'on les deduit des profils de teneur en isotope de l'oxygène. Les recherches sur les profils en isotopes et en températures dans les calottes polaires ont surtout été menées indépendemment l'une de l'autre jusqu'en 1973, année d'une rencontre de travail à Cambridge sur les deux sujets. L'étude des profils de températures montre la validité approximative des distributions de températures établies théoriquement pour des modèles de calottes en équilibre, alors que d'autres analyses aident à déterminer les écarts par rapport à l'état d'équilibre. Une revue donne quelque idée du degré de précision des différentes solutions de l'étude de la distribution flux de chaleur/température dans les calottes glaciaires. Beaucoup de ce que l'on sait est directement applicable à l'interprétation des profils isotopiques, si une correspondance directe peut être établie entre les valeurs isotopiques moyennes $\delta$ et les températures moyennes annuelles. L'article examine donc les différentes manières de comparer les valeurs $\delta$ et les températures, et montre que pour les régions centrales des calottes polaires une relation cohérente entre ces facteurs existe bien.

Zusammenfassung. Zusammenführung von Temperatur-Tiefen-Profilen in polaren Eisdecken und früheren Oberfächentemperaturen, hergeleitet aus Sauerstoffisotopen-Profilen. Untersuchungen von Isotopen- und Temperaturprofilen in polaren Eisdecken wurden meist unabhängig voneinander durchgeführt, bis im Jahre 1973 ein Seminar über beide Verfahren in Cambridge abgehalten wurde. Studien der Temperaturprofile zeigen die angenäherte Gültigkeit theoretisch abgeleiteter Temperaturverteilungen für stationäre Modelle von Eisdecken, während andere Analysen zur Bestimmung der Abweichungen vom stationären Zustand beitragen. Die Zusammenstellung gibt einen Eindruck von der Genauigkeit verschiedener Ansätze für die Verteilung des Wärmeflusses und der Temperatur in Eisdecken. Viele dieser Einsichten sind für die Deutung von Isotopen-Profilen unmittelbar anwendbar, wenn ein direkter Zusammenhang zwischen den mittleren isotopischen $\delta$-Werten und der mittleren Jahrestemperatur festzustellen ist. Die Arbeit diskutiert daher verschiedene Methoden des Vergleichs von $\delta$-Werten und Temperaturen und weist nach, dass im Zentralbereich von polaren Eisdecken zwischen diesen beiden Faktoren eine ausreichend konsistente Beziehung besteht.

\section{INTRODUCTION}

The rather lengthy title of this paper originally defined the programme of an international Workshop held at the Scott Polar Research Institute, Cambridge, England during the early part of 1973 (Robin, r973). Glaciologists from Australia, Canada, France, Demark, U.S.A., and Britain gathered to discuss the interaction of two fields of study: namely, temperature profiles and oxygen-isotope profiles in polar ice sheets. Exchange of ideas on these two themes proved so fruitful and lively that we decided to publish a book on the subject. All the main participants in the Workshop have contributed, the material is now being drawn together in Cambridge under my general editorship, and the monograph will be published shortly by the Cambridge University Press (Robin, in press).

Over the past 20 years substantial advances have been made in the study of both temperature and of isotopic profiles of ice sheets, but until 1973 there was little direct interchange of thought on the results of analyses. The major factor in making such an interchange worthwhile and even essential was the recovery of the surface-to-bedrock ice cores from the deep ice 
at Camp Century, Greenland in 1966, and from "Byrd" station in west Antarctica in r968. Temperature profiles and ice-core studies from other areas, such as Law Dome, Terre Adélie, and Vostok station in Antarctica, and from Devon Island and further stations on the Greenland ice sheet are adding to our fund of knowledge to such an extent that we have gained confidence in interpretation of the available material. This material will be valuable not only to glaciologists but also to climatologists, oceanographers, geologists, and in fact to anyone whose studies are influenced by the climatic history of the Earth over the past million years.

There has been an understandable reluctance to accept simple interpretations of oxygenisotope profiles in ice sheets as a record of climatic (temperature) variation with time. Although there are sound reasons for this, the potential importance of such profiles is so great that it is worth a considerable effort to understand the factors that govern the development of these isotopic profiles. Such knowledge makes it possible to decide how much climatological information can be derived with confidence from a particular ice core, or how much the record in the core is affected by the flow of the ice sheet and other factors. In many cases the isotopic record itself can help us deduce the pattern of flow in the ice sheet, including past variations.

Much of the basic thinking necessary for the above purposes has already been done in studies of the interaction between the flow pattern and temperature distribution of polar ice sheets. Such studies have made it possible to draw conclusions about the state of balance of ice sheets, the amount of ice movement, and the effects of surface temperature changes on deep ice temperatures. These results have proved most useful over periods ranging from decades to perhaps ten thousand years. In cases where we can interpret the isotopic records with confidence, we should be able to obtain much more detailed information over periods up to several hundred thousand years. In this paper it is first necessary to review our interpretation of ice temperature profiles, in order to show how we can apply similar considerations to isotopic profiles. Apart from the general statement of the problem in the following paragraph, we shall refer readers to other papers for mathematical formulation of the problems (Budd and Radok, 197I; Shumskiy and others, [1964]) and concentrate on the assumptions involved in the different models and the merits of the results obtained.

\section{ANALysis AND GALCULATion OF TEMPERATURE PROFILES}

The rate of change of temperature with time $(\partial \theta / \partial t)$ at any fixed point within a polar ice mass is determined by a vector equation involving the temperature of the ice moving past the point with velocity $\mathbf{v}$ through an advection term $\rho c \mathbf{v} \cdot \nabla \theta$ where $\rho$ is the ice density and $c$ its specific heat capacity, by the heat flux divergence at that point $\nabla \cdot(k \nabla \theta)$, where $k$ is the thermal conductivity of ice, and by the rate of heat generation per unit volume $Q$ within the ice mass. This last term is primarily the result of the heat generation due to work done in deforming the ice mass. The basic equation can be written

$$
\rho c \frac{\partial \theta}{\partial t}=\rho c \mathbf{v} \cdot \nabla \theta+Q-\nabla \cdot(k \nabla \theta) .
$$

In order to solve this equation in practical cases it is necessary to introduce certain simplifications and approximations. First and foremost is the assumption that the ice sheet is in a steady state. By this we mean that it is of constant size and shape and that its boundary conditions are not changing. In other words, mean surface temperature, the mass balance at any point, and the geothermal heat flux at the base of the ice are constant. It is implicit in these assumptions that the velocity and temperature distributions throughout the ice sheet do not change with time.

A detailed solution in three dimensions to the steady-state velocity and temperature distribution in an ice sheet is very complex, although the introduction of electronic computing 
techniques has produced rapid advances in our techniques of modelling. A particularly useful approximation is to convert the problem to that of one dimension by considering the temperature distribution in a vertical column of ice undergoing uniform vertical strain. The results should apply near the centre of an ice sheet in a steady state, where the vertical velocity at the top of the column will be the same as the mean rate of accumulation of ice, so that Equation (I) can be simplified considerably. Solutions to this problem given in Robin (I955) and shown in Figure I show the great influence of the rate of accumulation on the temperature distribution in the steady-state model. For conditions encountered near the centre of Greenland, with an ice thickness of $3000 \mathrm{~m}$ and an accumulation rate of about $30 \mathrm{~cm}$ ice $\mathrm{a}^{-1}$, upward flow of heat from the base of the ice does not penetrate more than half-way to the surface, due to advection of heat through downward and outward motion of the ice. One temperature measurement by a thermal probe near the centre of the Greenland ice sheet (Philberth, I970) shows that from 220 to I $000 \mathrm{~m}$ depth the ice is isothermal to within $\mathrm{I}$ deg, which agrees with Figure $\mathrm{I}$ as the local accumulation rate is about $32 \mathrm{~cm}$ ice $\mathrm{a}^{-1}$. This immediately suggests that our steady-state assumption is likely to correspond reasonably closely to actual conditions.

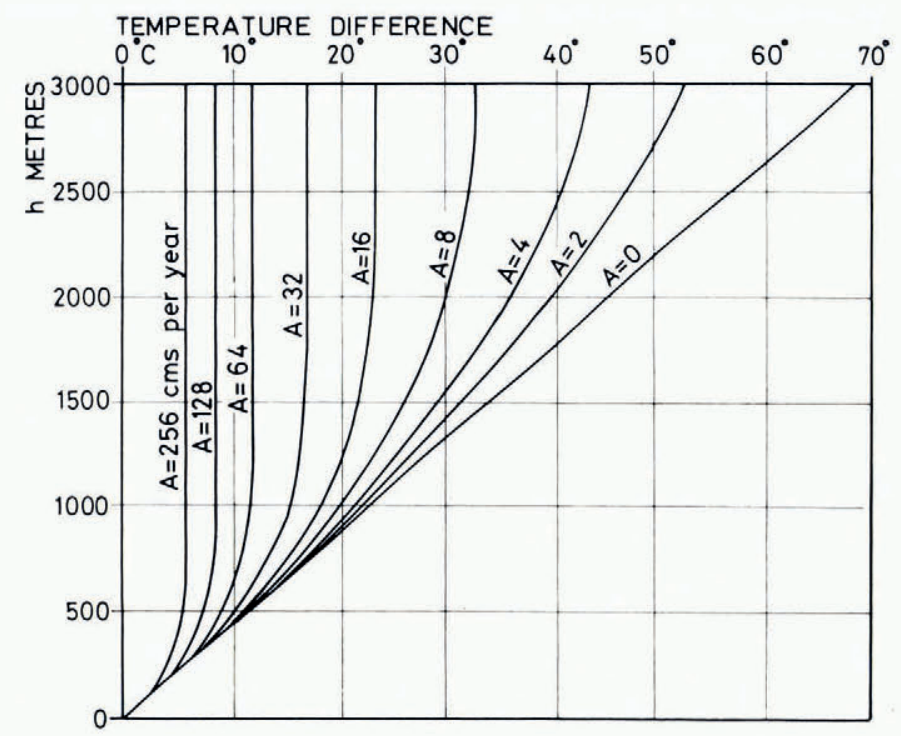

Fig. I. Temperature difference between the base and higher levels of a polar ice sheet of a constant thickness of 3 ooo $m$ as a function of the surface mass balance according to Robin (I955).

The vertical-column model is still useful away from the centre of the ice sheet, but one must allow for a variable vertical strain-rate as the ice flows over a rough bedrock relief and also thins as one moves out towards the boundary. This type of model, adapted for electronic computing techniques, has been used very effectively to assess the "Derived physical properties of the Antarctic ice sheet" by Budd and others (1971[a]). Figure 2 summarizes their very extensive computations along a flow line from Vostok station near the centre of the eastern Antarctic ice sheet to Wilkes station on the coast. Information on ice depths, accumulation rates, and ice temperatures up to $70 \mathrm{~m}$ depth has been obtained from surface traverses along this line. Calculated temperature gradients and the depth of "isochrones" (the position in the ice sheet now occupied by a layer that formed the surface at a given time in the past) are very sensitive to the rate of accumulation of ice on the surface. For this study, accumulation 
rates varied from $5 \mathrm{~cm}$ ice $\mathrm{a}^{-1}$ at Vostok station $\left(3700 \mathrm{~m}\right.$ altitude) to around $25 \mathrm{~cm}$ ice $\mathrm{a}^{-1}$ near the coast. The diagram in Figure 2 illustrates the major problems involved in interpreting bore-hole studies, including isotopic data, from any location along the flow line. Thus for a bore hole at $900 \mathrm{~km}$, the oldest ice distinguished on the diagram is nearly 200 ooo years old; still older ice may be compressed into a small layer at the base so that it would be difficult to study in practice. Although the surface ice temperature at $800 \mathrm{~km}$ is $-43^{\circ} \mathrm{C}$, ice near the base will have travelled some $600 \mathrm{~km}$ and been deposited at a temperature of about $-60^{\circ} \mathrm{C}$. We should therefore expect corresponding changes to be present in the isotopic record. On the computed temperature profile, one notes that the ice temperature at $800 \mathrm{~km}$ becomes colder for the first $\mathrm{I}$ ooo $\mathrm{m}$ increase in depth. A similar but stronger effect is seen as one moves towards the coast, but is not present further inland. Observed temperature gradients to $70 \mathrm{~m}$ depth along the profile are in approximate agreement with these calculations. The effect is due to advection of colder ice from further inland beneath warmer surface layers, as suggested by Robin (1955). In regions with high rates of accumulation of ice, especially with considerable ice depths, horizontal advection often dominates the temperature gradients in the upper part of the ice sheet. Results from Law Dome, Antarctica (Budd and others, I976), Greenland, and along various Antarctic traverses provide ample evidence that this explanation of negative temperature gradients is correct, although superimposed on this is the effect of climatic changes.

The accuracy of the information presented in Figure 2 is limited both by the accuracy of the information fed to the computer and by the validity of the flow model that is assumed. Recent studies of the ice sheet by radio-echo methods have shown the presence of lakes beneath

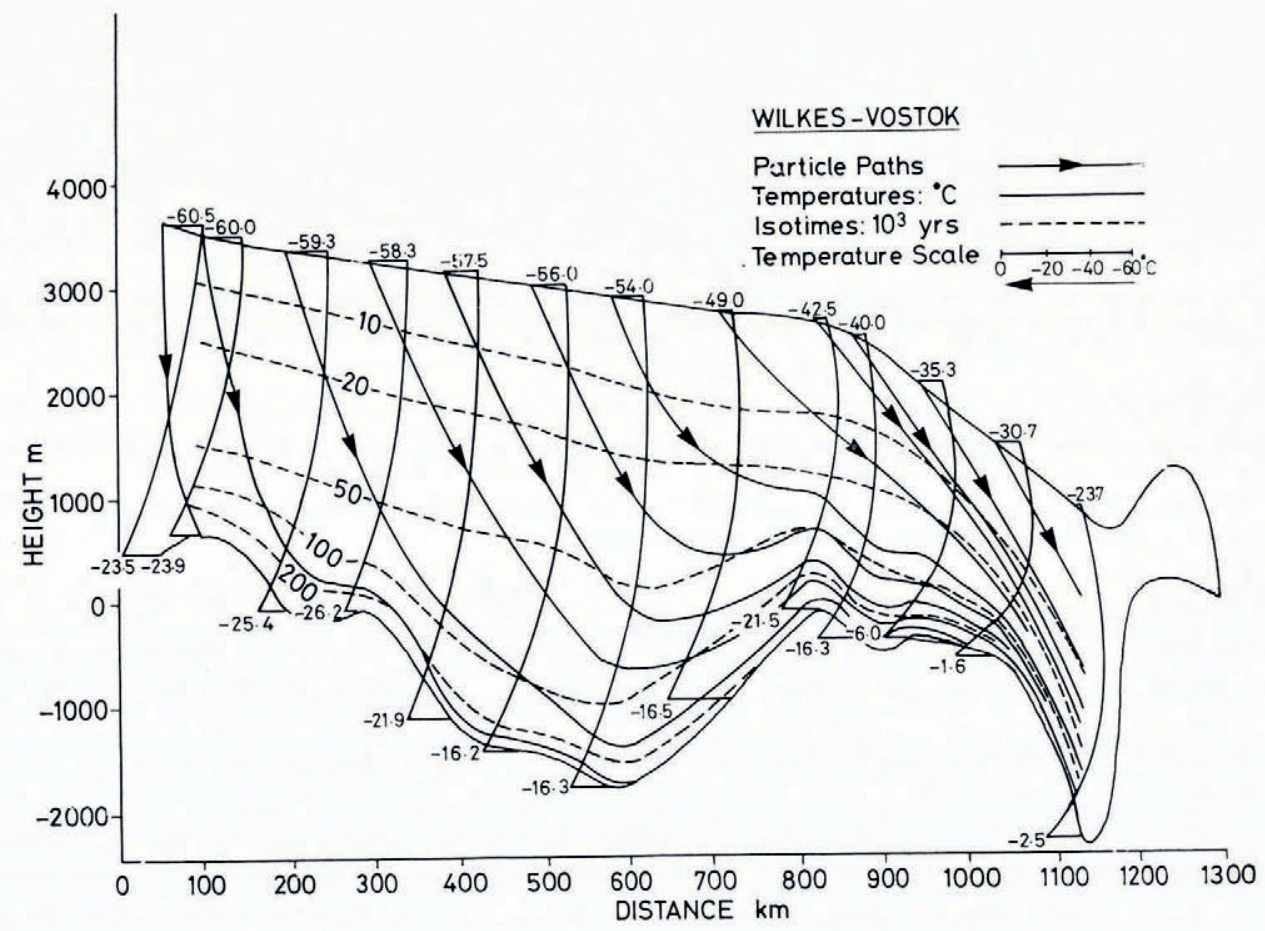

Fig. 2. Trajectories (arrows), isochrones ( $1 \mathrm{O}^{3}$ years, broken lines) and temperature-depth profiles ( full lines) along an approximate flow-line from Vostok to Wilkes stations in Antarctica (from Budd and others, $1971[a]$ ). 
at least $2900 \mathrm{~m}$ of ice in areas near this profile (Oswald and Robin, r973) and further studies indicate that much of the base of the ice from 400 to $700 \mathrm{~km}$ on this profile is probably at the melting point (Oswald, unpublished). This indicates temperatures at least $13^{\circ} \mathrm{C}$ warmer than those shown in Figure 2. Recomputation of profiles in the vicinity of the sub-ice lakes indicates that these discrepancies can be explained by inaccuracies of the data fed to the computer, such as the value of the geothermal flux and especially the rate of accumulation in central Antarctica.

In contrast with the preceding case, comparisons of computed and observed temperature profiles for the bore hole at Camp Century, Greenland, show that discrepancies are largely due to the theoretical models used. Figure 3, from Philberth and Federer (1971), shows a comparison of the computed and observed temperature gradients at Camp Century. The input data consisted of surface ice temperatures, surface mass balance (net accumulation rate), and the basal temperature gradient or geothermal flux. The main difference between the predictions are that Weertman and Robin assumed a uniform vertical strain throughout the ice, whereas Philberth and Federer assumed strain-rates that decreased to zero at bedrock and were closely related to the variation of horizontal velocity of ice motion with depth. Dansgaard and Johnsen (1969) used arguments similar to those of Philberth and Federer on a more empirical basis and produced similar results. The improvement with a better model of vertical strain is apparent in Figure 3, but it is not conclusive. Independent calculations reported at the Cambridge Workshop by three participants all showed that the temperature gradient at $\mathrm{I} 400 \mathrm{~m}$ depth was still likely to be changing with time due to residual effects

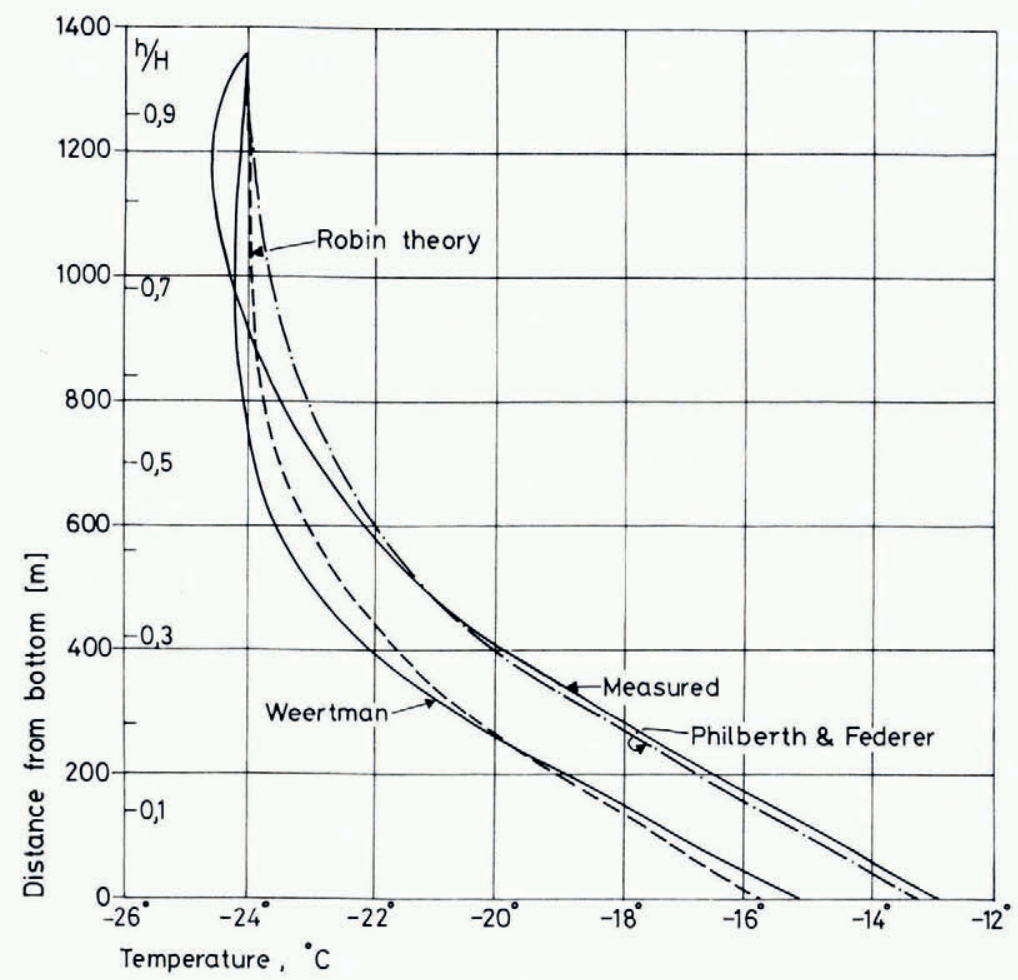

Fig. 3. Comparisons of measured temperature profile at Camp Century, Greenland, with theoretical profiles calculated on the basis of a uniform vertical strain-rate (Weertman and Robin theory) and a variable vertical strain-rate that decreases to zero at bedrock ( from Philberth and Federer, 1.97I). 
from changes of surface temperature at the end of the last ice age, 15 ooo to ro ooo B.P. We can summarize the evidence so far by saying that temperatures predicted on a steady-state model of ice sheets appear to agree approximately with the available observed temperaturedepth profiles, but precise agreement is not expected due to lack of precise data and accurate models of the deformation of ice sheets.

Further confidence in the general validity of our interpretations comes from other studies such as equations introduced by Zotikov (I96r[a], [b]) and Weertman ( $196 \mathrm{I}$ ) to allow for the effect of melting or freezing at the base of an ice sheet. These equations are particularly important in the case of Antarctic ice shelves, where predictions of strong bottom melting beneath the Maudheim Ice Shelf and the Ross Ice Shelf at Little America V, and of considerable freezing beneath part of the Amery Ice Shelf, made on the basis of temperaturedepth profiles, have all been confirmed by mass-balance studies (Crary, I96r ; Swithinbank, 1962) or by isotopic measurements (Morgan, 1972).

Another approach is to reverse the argument and use temperature-depth profiles to determine the mean boundary conditions. This is done by numerically fitting differential equations describing an appropriate model to an observed temperature-depth profile. The basic parameters that come from this work are a figure for the vertical velocity at the ice surface, usually taken as being equal to the accumulation rate, the rate of change of surface temperature of the ice column and the basal temperature gradient. In Robin (1955) such curve fitting was used in conjunction with the steady-state assumption to determine the accumulation rate and ice movement at Camp VI in Greenland. Budd and others (197 I [b]) have introduced an elegant method of curve fitting using a least-squares adjustment with a uniform vertical strain-rate model. This was first applied to the Camp Century temperature profile and subsequently to profiles from "Byrd" station and to an unpublished analysis for Vostok. In all cases, figures for the most probable accumulation rates (Budd and others, I97 I [b], [1973]) agree with observed values to within the accuracy of the observations, which is about 10 to 20 per cent of the total rate. Figures for the rate of change of surface temperature with time need further discussion.

\section{Climatic change and temperature profiles}

So far our discussion has aimed at explaining the observations of temperature distribution in polar ice sheets in terms of realistic models of ice flow. Once confidence in the model is established, it is natural to see if we can deduce past temperature changes from analysis of temperature distribution. Unfortunately there is no unique solution to the problem. A temperature-depth profile presents the integrated effects of surface climatic changes, of geothermal and frictional heat fluxes, of the present flow, and of past changes of flow of the ice sheet. We need to introduce simplifying assumptions if we are to find a solution. Figure 4 shows the results of attempting to explain the observed temperature-depth curves in the upper

Fig. 4. Comparison of temperature measurements $(+)$ with temperature-depth profiles calculated on the basis of a single jump of temperature, the amount of the jump for each chosen date being adjusted to pass through the observed temperature at $60 \mathrm{~m}$ depth (Station Centrale, $4 a)$ or $80 \mathrm{~m}$ depth (Site 2, $4^{b}$ ) and to approach the limiting temperature at greater depth. The size of the jumps were:

Station Centrale:

$+1.45 \mathrm{deg}$ in 1930 , shown by

$+0.86 \mathrm{deg}$ in 1920 , shown by $\times$

Temperatures observed in 1950.

Site 2:

\footnotetext{
$+2.75 \mathrm{deg}$ in 1930 , shown by

$+1.66 \mathrm{deg}$ in 1920 , shown by $\times$

+1.13 deg in 1910 , shown by 0

Temperatures observed in 1956 and 1957.
} 

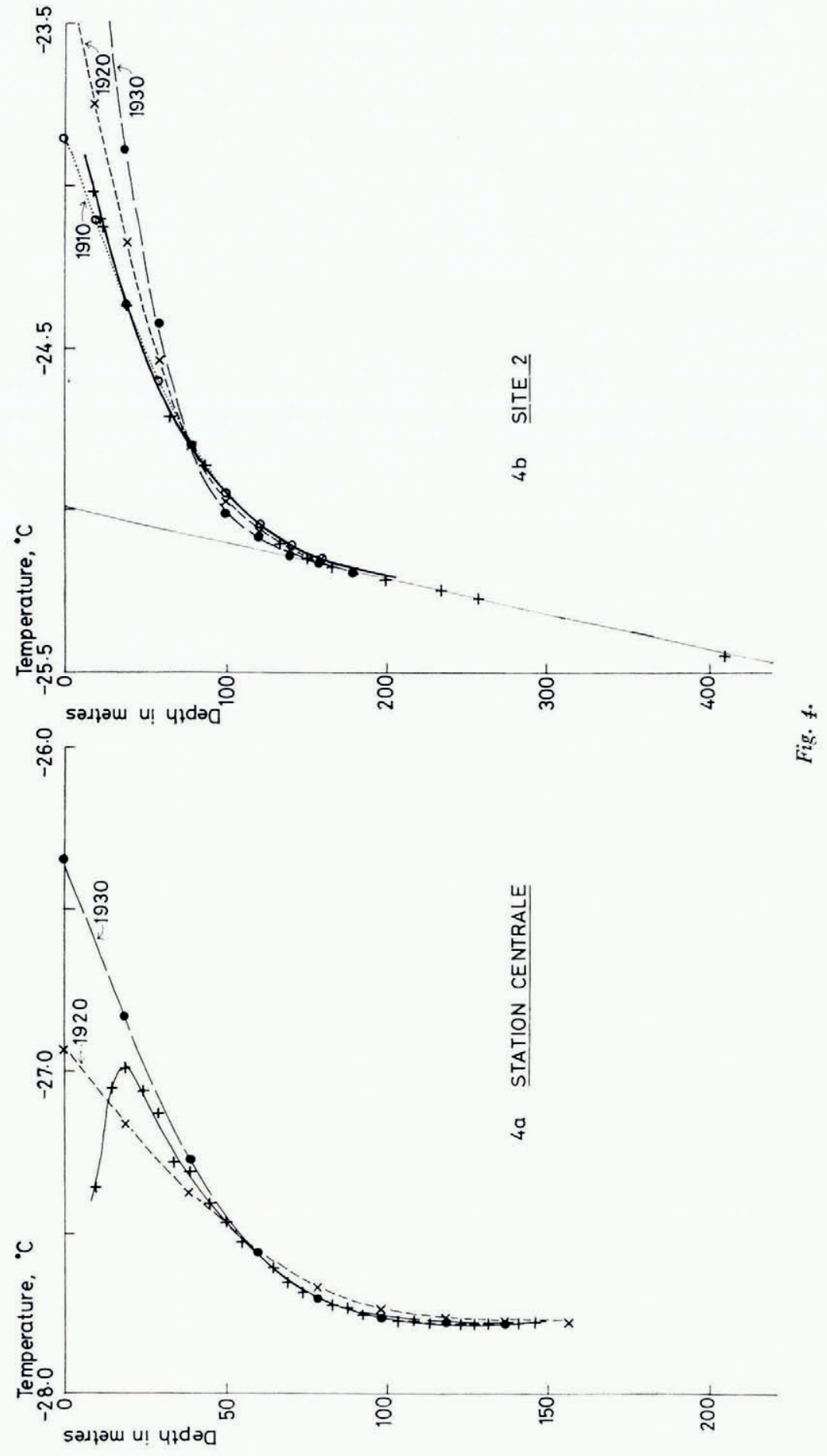
layers of the Greenland ice sheet at Station Centrale and Site 2 by fitting temperature-depth curves that allow for a single temperature jump at the surface and a vertical velocity of the ice mass equal to the rate of ice accumulation at the surface. Density changes with depth are neglected as effects will be small below $50 \mathrm{~m}$ depth. The equation used is a simplified version of that given by Carslaw and Jaeger (1959, p. 388, eq. 7). The variable parameters are the amplitude and the date of the jump, and curves were calculated to pass through the observed temperature at either 60 or $80 \mathrm{~m}$ depth and to approach the limiting temperature at greater depth. Below $30 \mathrm{~m}$ depth the best fit for Station Centrale (Fig. 4a) comes from assuming a temperature rise of $1.45 \mathrm{deg}$ in 1930 , while at Site 2 (Fig. 4 b) a reasonable fit is obtained by assuming a rise of $1.13 \mathrm{deg}$ in 1910 , although below $120 \mathrm{~m}$ the fit is better for the 1920 curve.

\section{ISOTOPIC-TEMPERATURE GOMPARISONS}

Dansgaard and others (1973) have reviewed factors governing the distribution of stable isotopes in polar ice sheets in considerable detail and have discussed the relationship between mean annual temperature and isotopic composition. If this relationship were simple and did not vary with time, we could use the isotopic values from an ice core to provide a continuous record of the temperature of the ice in the core at the time of its deposition. The problem is then reduced to finding the location at which the ice was deposited along the lines shown in

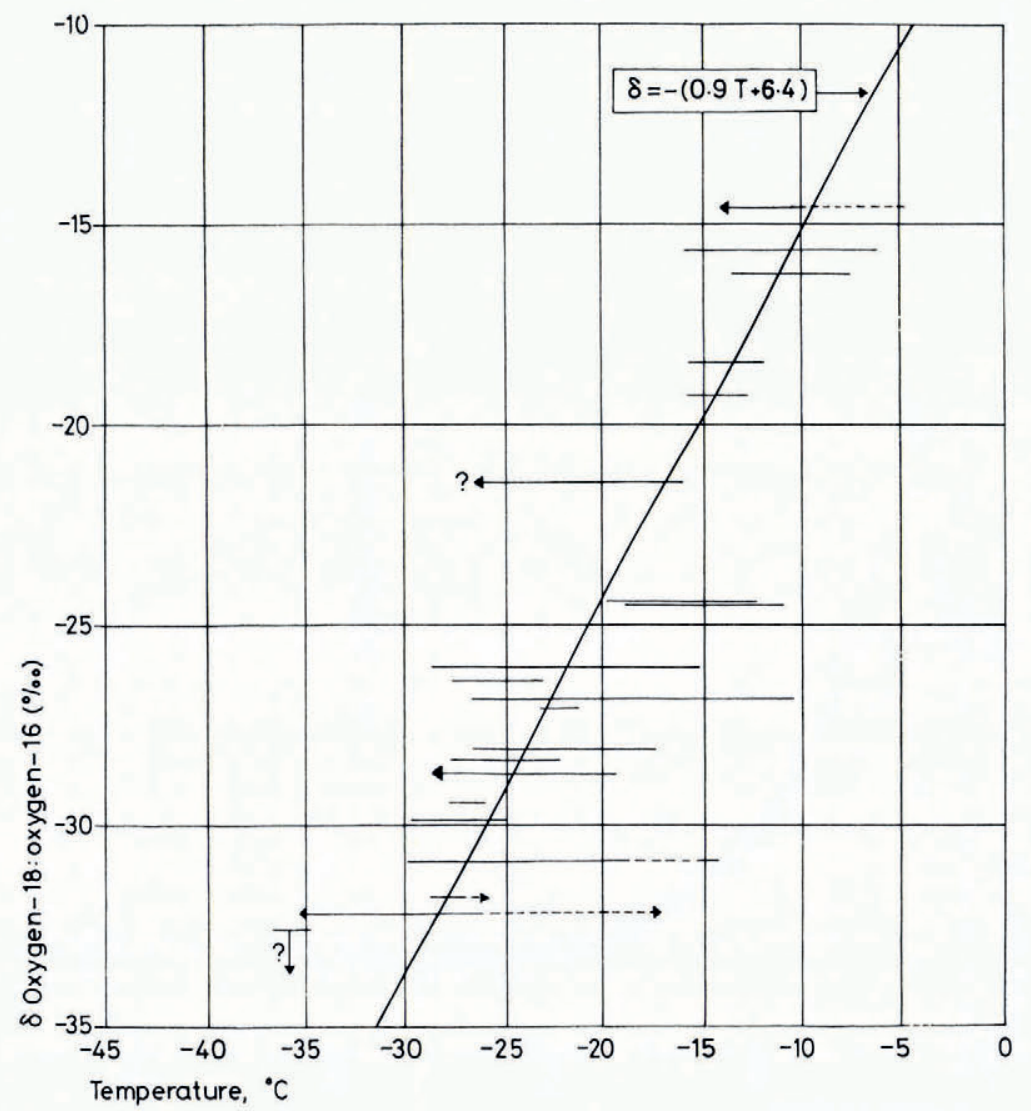

Fig. 5. Isotopic composition of oxygen in snowfalls plotted against the temperature in the corresponding cloud sheet (from Picciotto and others, 1960$)$. 
Figure 2, so that we can allow for any change in size of the ice column with time in order to use our "isotopic temperatures" to determine past changes of climate.

Before we can take the highly desirable steps outlined above, we must first see if our "Reconciliation of temperature-depth profiles in polar ice sheets with past surface temperatures deduced from oxygen isotope profiles" is justified. This was the main task of the Cambridge Workshop, which was conceived with the object of seeing if, by using the past "isotopic temperature" record from the ice core, we could calculate a resultant temperature-depth profile that was substantially closer to the observed values than that obtained from a steadystate calculation with constant climate. It is apparent from our discussion of factors governing temperature profiles that a number of variables have to be taken into account. However, the single most important variable is the surface temperature, especially with regard to the temperature of the uppermost layers, although past variations of accumulation rate and of the size and flow of the ice sheet have considerable effects at greater depth. The results of the Workshop, shortly to be published in a monograph by the Cambridge University Press, show that, in comparison with steady-state theory, a considerable improvement in the fit of calculated temperature-depth profiles to measured profiles is obtained by using "isotopic temperatures" as the input to a model which otherwise assumes a steady state as regards size, flow, and accumulation rate.

Since preparation of this review, further comparisons of a variety of climatic information with isotopic stratigraphy of the Greenland ice sheet by Dansgaard and others (1975) also justify the use of "isotopic temperatures" on an empirical basis, but the evidence does little to explain the physical processes involved. Isotopic ratios in polar snow are determined by the past history of the air mass in which the snow is formed, and by the cloud temperatures at the time of formation. Picciotto and others ( 1960 ) determined the mean values for ${ }^{18} \mathrm{O} /{ }^{16} \mathrm{O}$ as a function of the temperature of the clouds above Roi Baudoin station on the coast of Antarctica (Fig. 5). In this figure, the ends of the data lines give the temperature at the base and top of the cloud, as determined by radio-sonde data at the time of precipitation. They obtained the relationship $\delta=0.9 T^{\prime}+6.4$ where $T^{\prime}$ is the mean cloud temperature in degrees Celsius. However, for glaciological studies we need to use a relationship between mean annual temperatures and isotopic $\delta$ values. Dansgaard and others (1973) have provided a plot of the relevant information from Greenland and Antarctica (Fig. 6). There appears to be a consistent relationship between mean annual temperatures $T$ and isotopic values for the Greenland ice sheet, the slope of the best-fit straight line giving $\mathrm{d} \delta / \mathrm{d} T=0.62 \mathrm{deg}^{-1}$. The points are more scattered for the Antarctic ice sheet, but Lorius (1973), on carefully selected samples in eastern Antarctica, obtained $\mathrm{d} \delta / \mathrm{d} T=0.76 \mathrm{deg}^{-1}$. The slope of the left-hand line in Figure 6 is close to I.o. Gordiyenko and Barkov (1973) find a slope of 0.84 from results at Soviet Antarctic stations. Although the figures vary, there is at least a rough agreement between different sets of data that suggests that the mean temperatures in the clouds that produce the snow are approximately related to the mean annual temperatures at the same sites. Such agreement is more likely to occur over the relatively uniform slopes of large polar ice sheets than in other locations where the underlying surface is less regular. In mountainous regions, for example, snow forming in the higher clouds is likely to fall both in the valleys and on the mountain tops, although there will be a considerable difference in mean annual temperature between such sites.

Seasonal variations of cloud temperatures in relation to the $\delta$ values of deposited snow were included in the studies of Picciotto and others (1960) on the Antarctic coast while Aldaz and Deutsch (1967) made similar studies at the South Pole. Both sets of results explain satisfactorily the well-known seasonal variations of $\delta$ values that have been shown by Dansgaard and others (1973) to provide a useful means of determining former mass balances and should make possible the dating of ice cores up to io ooo years old. At the same time we must expect some difference between the variations of mean annual temperature and those of mean $\delta$ 


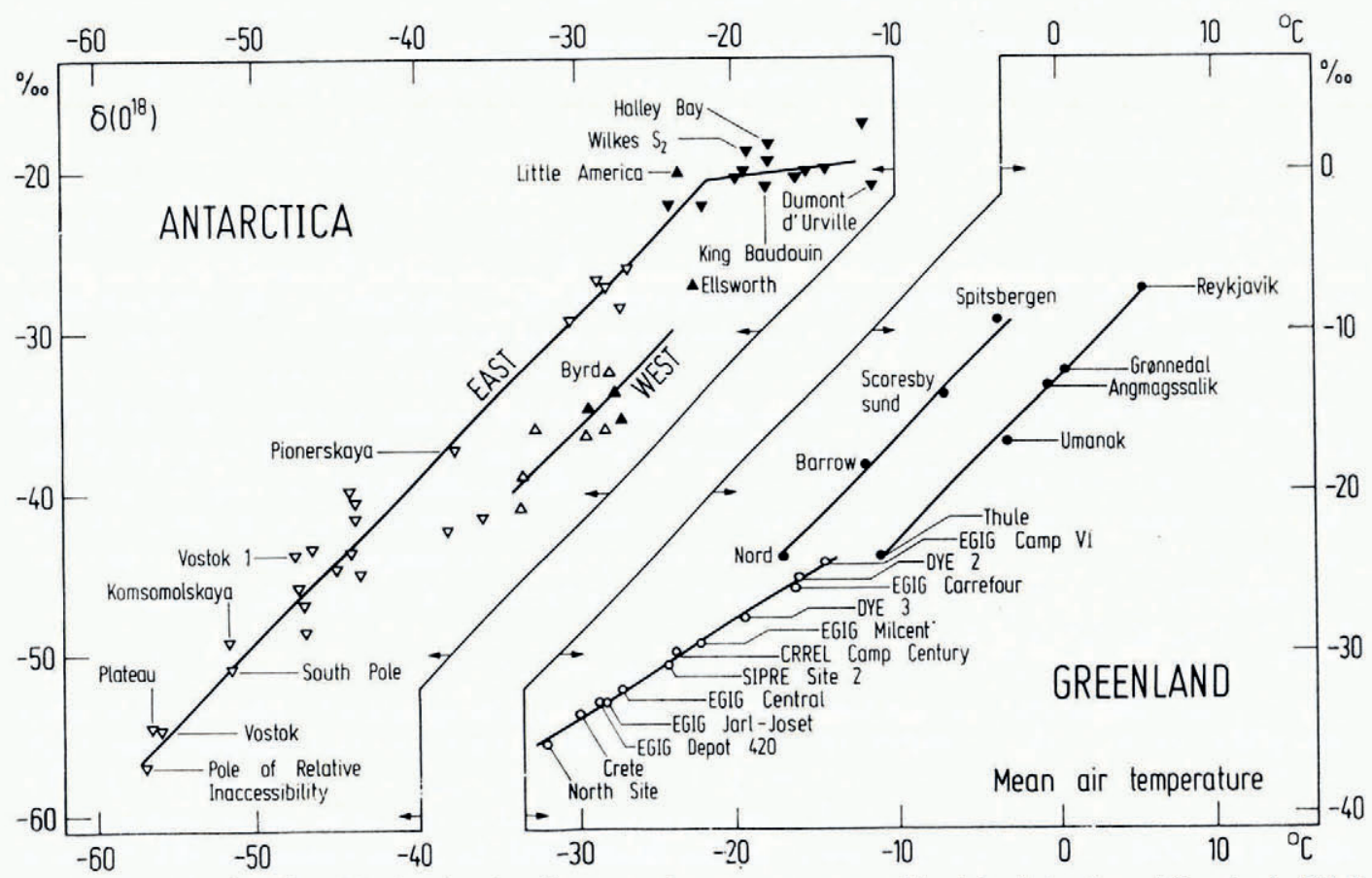

Fig. 6. Mean $\delta$ value of precipitation plotted against mean air temperature at ground level for Antarctica and Greenland. Filled circles or triangles are for stations below $\mathrm{I}$ ooo $\mathrm{m}$ altitude, open circles are above I ooo $\mathrm{m}$ altitude (from Dansgaard and others, I973, reproduced by permission of Meddelelser om Gronland).

values. Such differences could arise from changes in the proportion of winter to summer snowfall, from changes of cloud cover affecting temperature conditions, or from mass exchange by diffusion between annual layers in the upper firn. However, use of a sufficiently long time interval should average out this type of statistical fluctuation. Some analyses at the Cambridge Workshop using 50 year mean values from Camp Century gave predictions of temperature profiles that matched observed temperature profiles to better than $0.5 \mathrm{deg}$ at depths below $200 \mathrm{~m}$. When other factors affecting the accuracy of the fit are taken into account, it would seem that long term isotopic mean values can be used to indicate long term variations of temperature to a fraction of $0.5 \mathrm{deg}$. However, much larger differences between calculated and observed temperature profiles occurred when using 5 year means.

Dansgaard and others (1973) have used ro year running-mean values for both temperature and isotopic $\delta$ values in compiling Figure 7 . In this Figure, an attempt is made to overcome the lack of climatic data from inland sites on ice sheets by comparing isotopic values dated by stratigraphy from sites on the Greenland ice sheet with climatic records obtained from meteorological stations on the east (Upernavik) and west (Angmagssalik) coasts of Greenland. Unfortunately the various locations are hundreds of kilometres apart, but there still appears to be a considerable amount of correlation between the temperature records on the coast and $\delta$ values on the ice sheet, especially in relation to the warming spell in the late 1920 's. We note, however, the lack of a similar correlation around igro where isotopic values suggest some warming on the ice sheet at Dye 3 and strong warming at Camp Century, but no such temperature effect is present in the temperature records from the coast. Although Dansgaard and others (1973) query the reliability of the lower part of the Camp Century record, our relatively crude model in Figure $4 \mathrm{~b}$ for Site 2, only $100 \mathrm{~km}$ from Camp Century, showed that 


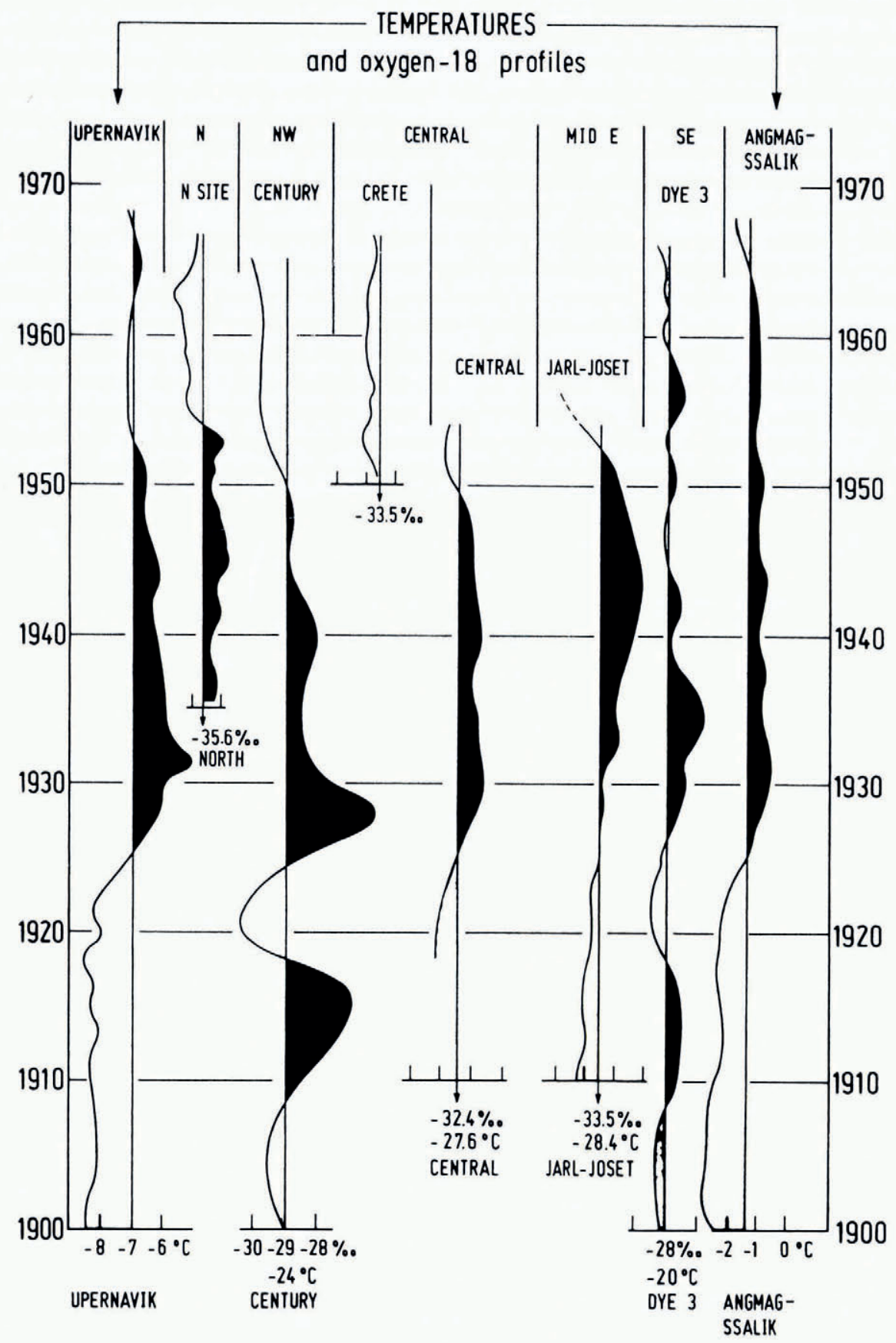

Fig. 7. Observed Io year running-mean temperatures from Greenland coastal stations (Upernavik, outer left, and Angmagssalik, outer right) compared with Io year running-mean $\delta$ values at six Greenland ice-sheet stations. The lower part of the Camp Century $\delta$-record may not be fully reliable (from Dansgaard and others, 1973, reproduced by permission of Meddelelser om Grenland). 
an assumed temperature rise of I.I deg in I9Io produced a calculated temperature profile that was in qualitative agreement with the isotopic profile, since this showed strong warming equivalent to several degrees Celsius around igio followed by a cooler period around 1918. Furthermore, the temperature rise of $1.45 \mathrm{deg}$ in 1930 suggested for Station Centrale in Figure $4 \mathrm{a}$ is in agreement with the isotopic evidence at Station Central and Jarl-Joset. Both these crude analyses, that were made by the author before any isotopic data were available, show at least semi-quantitative agreement with the isotopic data in Figure 7.

Let us now return to the attempts to determine long-term temperature changes at the surface of a moving column of ice from temperature profiles (Budd and others, I97I[b]; [1973]) and compare these figures with the relevant isotopic data. This is done in Figure 8 for "Byrd" station and Camp Century by the straight lines, the slopes of which correspond to the mean rates of change of surface temperatures. Budd and others suggest that their derived rate of change of temperature at Camp Century should represent trends over a period of $1^{4}$ years, but we see from Figure 8 that the relevant period appears to be overestimated, although the trend given by the temperature analysis fits the general trend over the past 4000 years at "Byrd" station and a period of possibly only 2500 years at Camp Century. This appears reasonable when we remember that the upper part of the temperaturedepth curve is dominated by more recent changes, including advection effects, and that for

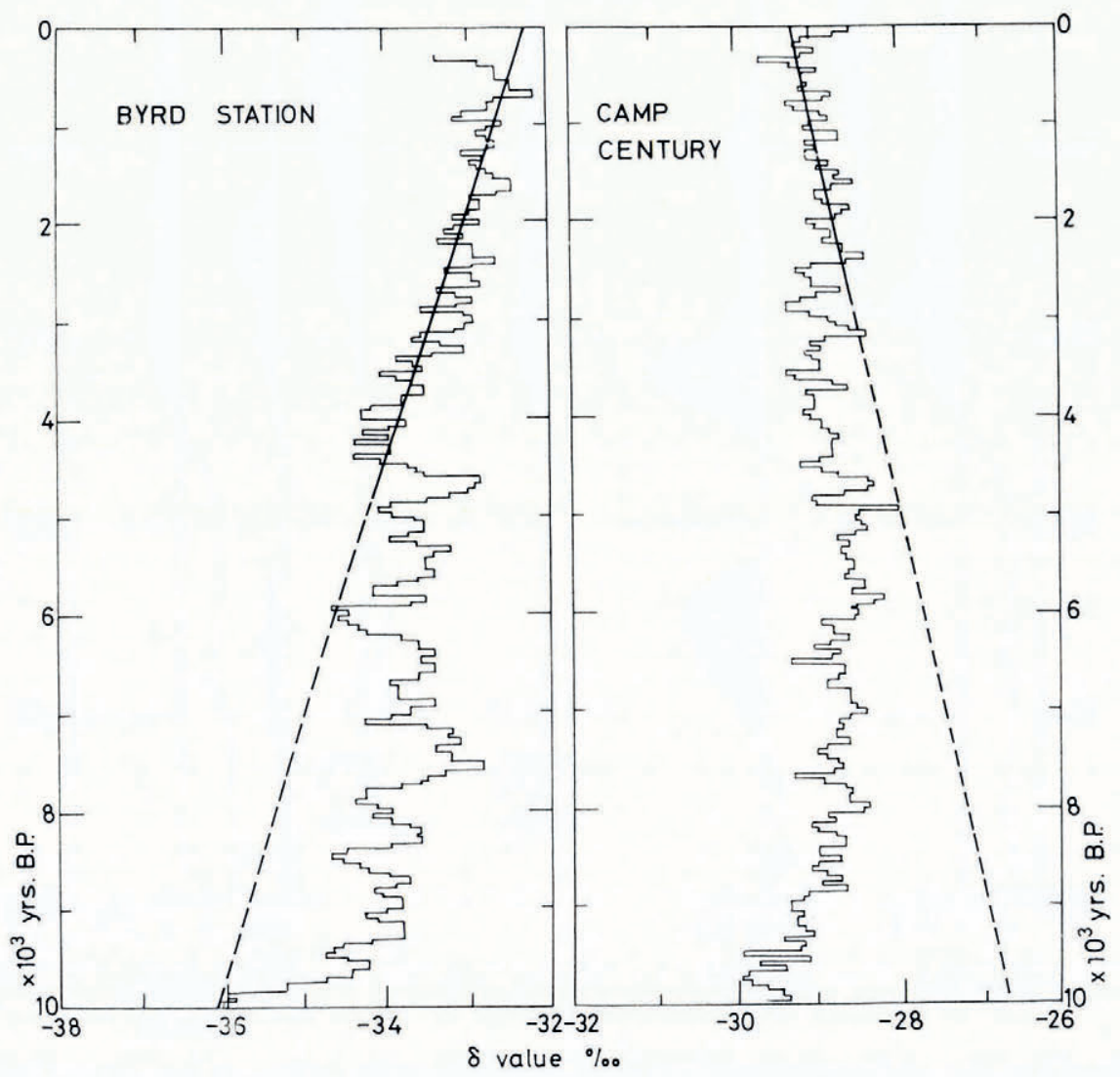

Fig. 8. Comparison of isotopic profiles for "Byrd" station and Camp Century from Johnsen and others (1972) with the rate of surface temperature change for the same ice column deduced by Budd and others (I97I [a], [1973]) and shown by the straight lines. Conversion from temperature to isotopic scales for these lines have used the relationships $\delta=(o .76) T+\dot{b}^{\prime}$ for "Byrd" station and $\delta=0.62+b$ " for Camp Century where $b$ ' and $b$ " are arbitrary constants. 
these levels the approximations introduced by use of a moving column model and uniform strain-rate are not too serious. In contrast, the deeper ice temperatures are not only more difficult to model satisfactorily, but they also contain residual effects of colder temperatures more than Io ooo years ago. Nevertheless, even the limited agreement between temperature and isotopic data in Figure 8 is encouraging when taken together with the successful estimates of accumulation rates at the same sites.

It is clear from the preceding examples that there is a considerable body of evidence in favour of the use of isotopic $\delta$ values as a past record of mean surface temperatures of polar ice sheets. We are also building up an understanding of when such information can and cannot be used for this purpose. The peripheral areas of Antarctica are probably unsuitable, while central areas of the ice sheets of Greenland and Antarctica appear to be most suitable and are worth much further study. The support that has been given to the Cambridge Workshop by the participants and funding bodies to make a more detailed assessment of these problems, and the belief of the participants that a monograph should be published, emphasizes the value of studies of profiles of temperatures and isotopic values.

\section{REFERENCES}

Aldaz, L., and Deutsch, S. 1967 . On a relationship between air temperature and oxygen isotope ratio of snow and firn in the South Pole region. Earth and Planetary Science Letters, Vol. 3, No. 3, p. 267-74.

Budd, W. F., and Radok, U. 1971. Glaciers and other large ice masses. Reports on Progress in Physics, Vol. 34, No. 1 .

Budd, W. F., and others. $197 \mathrm{I}[\mathrm{a}]$. Derived physical characteristics of the Antarctic ice sheet. Mark I, by W. F. Budd, D. Fenssen and $U$. Radok. Melbourne, University of Melbourne, Meteorology Dept. (University of Melbourne. Meteorology Dept. Publication No. i 8.)

Budd, W. F., and others. $197 \mathrm{I}[\mathrm{b}]$. Reinterpretation of deep ice temperatures, [by] W. F. Budd, D. Jenssen, U. Radok. Nature, Physical Science, Vol. 232, No. 30, p. 84-85.

Budd, W. F., and others. [1973.] Temperature and velocity interaction in the motion of ice sheets, by W. F. Budd, D. Jenssen and N. W. Young. First Australasian Conference on Heat and Mass Transfer, held at Monash University, Melbourne, Australia, 23, 24, 25 May [1973]. Melbourne, Monash University, Sect. I, p. 17-24.

Budd, W. F., and others. 1976. Measured and computed temperature distributions in the Law Dome ice cap, Antarctica by W. F. Budd, N. W. Young and C. R. Austin. Fournal of Glaciology, Vol. 16, No. 74, p. 99-1 10.

Carslaw, H. S., and Jaeger, J. C. 1959. Conduction of heat in solids. Second edition. Oxford, Clarendon Press.

Crary, A. P. I96r. Glaciological regime at Little America station, Antarctica. Fournal of Geophysical Research, Vol. 66 , No. 3 , p. $87 \mathrm{r}-78$.

Dansgaard, W., and Johnsen, S. J. I969. Comment on paper by J. Weertman, "Comparison between measured and theoretical temperature profiles of the Camp Century, Greenland, borehole". Journal of Geophysical Research, Vol. 74, No. 4, p. I Io9-10; "Erratum", fournal of Geophysical Research, Vol. 74, No. 10, p. 2795.

Dansgaard, W., and others. 1973. Stable isotope glaciology, by W. Dansgaard, S. J. Johnsen, H. B. Clausen, and N. Gundestrup. Meddelelser om Gronland, Bd. 197, Nr. 2.

Dansgaard, W., and others. I975. Climatic changes, Norsemen and modern man, by W. Dansgaard, S. J. Johnsen, N. Reeh, N. Gundestrup, H. B. Clausen, and C. U. Hammer. Nature, Vol. 255, No. 5503, p. $24-28$.

Gordiyenko, F. G., and Barkov, N. I. 1973. Variatsii soderzhaniya $\mathrm{O}^{18} \mathrm{v}$ sovremennykh atmosfernykh osadkakh Antarktidy [Variations of $\mathrm{O}^{18}$ content in present atmospheric precipitation in Antarctica]. Informatsionnyy Byulleten' Sovetskoy Antarkticheskoy Ekspeditsii, No. 87, p. 40-43.

Johnsen, S. J., and others. 1972. Oxygen isotope profiles through the Antarctic and Greenland ice sheets, [by] S. J. Johnsen, W. Dansgaard, H. B. Clausen, C. C. Langway, Jr. Nature, Vol. 235, No. 5339, p. 429-34.

Lorius, C. 1973. Les calottes glaciaires, témoins de l'environnement. Recherche, Vol. 4, No. 34, p. 457-72.

Morgan, V. I. 1972. Oxygen isotope evidence for bottom freezing on the Amery Ice Shelf. Nature, Vol. 238, No. 5364 , p. $393-94$.

Oswald, G. K. A. Unpublished. Radio echo studies of polar glacier beds. [Ph.D. thesis submitted to the University of Cambridge, r 975 .]

Oswald, G. K. A., and Robin, G. de Q. 1973. Lakes beneath the Antarctic ice sheet. Nature, Vol. 245, No. 5423, p. $25 \mathrm{I}-54$.

Philberth, K. 1970. Thermische Tiefbohrung in Zentralgrönland. Umschau in Wissenschaft und Technik, 1970, Ht. 16 , p. 515-16.

Philberth, K., and Federer, B. 1971. On the temperature profile and the age profile in the central part of cold ice sheets. Fournal of Glaciology, Vol. 1o, No. 58, p. 3-14.

Picciotto, E. E., and others. 1960 . Isotopic composition and temperature of formation of Antarctic snows, by E. [E.] Picciotto, X. de Maere [d'Aertrycke] and I. Friedman. Nature, Vol. 187, No. 4740, p. 857-59.

Robin, G. de Q. 1955. Ice movement and temperature distribution in glaciers and ice sheets. Fournal of Glaciology, Vol. 2, No. 18, p. 523-32. 
Robin, G. de Q. 1973. Cambridge workshop on temperature and isotopic profiles in polar ice sheets, 1973 . Polar Record, Vol. I6, No. 105, p. 902-07.

Robin, G. de Q., ed. In press. Isotopic and temperature profiles in ice sheets. Cambridge, University Press. [Monograph arising from the 1973 Cambridge workshop, compiled by the main participants: W. F. Budd, D. Jenssen, S. J. Johnsen, C. Lorius, W. S. B. Paterson, G. de Q. Robin.]

Shumskiy, P. A., and others. [1964.] Ice and its changes, by P. A. Shumskiy, A. N. Krenke and I. A. Zotikov. (In Odishaw, H., ed. Research in geophysics. Vol. 2. Solid earth and interface phenomena. Cambridge, Mass., Massachusetts Institute of Technology Press, p. 425-6o.)

Swithinbank, C. W. M. r 1962 . Maudheim revisited: the morphology and regime of the ice shelf, $1950-1960$. Norsk Polarinstitutt. Arbok, i96o, p. 28-31.

Weertman, J. 1961. Equilibrium profile of ice caps. Journal of Glaciology, Vol. 3, No. 30, p. 953-64.

Zotikov, I. A. I96r[a]. Teplovoy rezhim lednika tsentral'noy Antarktidy [Thermal regime of the central Antarctic ice sheet]. Antarktika. Doklady Komissii, 1961, p. 27-40 [English translation: Jerusalem, Israel Program for Scientific Translations, 1966.]

Zotikov, I. A. rg6r[b]. Teplovoy rezhim lednika tsentral'noy Antarktidy [Thermal regime of the central Antarctic ice sheet]. Informatsionnyy Byulleten' Sovetskoy Antarkticheskoy Ekspeditsii, No. 28, p. I6-2 r. 